\title{
Resilience of the semi-arid tropical soils
}

\author{
T. Bhattacharyya ${ }^{1,3, *}$, D. K. Pal ${ }^{2}$, Suhas P. Wani ${ }^{1}$ and K. L. Sahrawat ${ }^{1, \dagger}$ \\ ${ }^{1}$ ICRISAT Development Center, International Crops Research Institute for the Semi-Arid Tropics (ICRISAT), Patancheru 502 324, India \\ ${ }^{2}$ Formerly at National Bureau of Soil Survey and Land use Planning, Nagpur 440 033, India \\ ${ }^{3}$ Dr Balasaheb Sawant Konkan Krishi Vidyapeeth, Dapoli 415 712, India
}

Soils in the semi-arid tropics (SAT) are subject to chemical degradation mostly due to climatic reasons which make the pedo-environment hostile to form calcium carbonate. This triggers an overall deterioration of soil properties affecting its physical and chemical parameters. Such soils require management interventions which may include chemical and other phytoremediation process. The present paper details this process of degradation in light of resilience of these soils of SAT.

Keywords: Chemical degradation, SAT, soil properties, soil resilience.

\section{Introduction}

THE soils of semi-arid tropics (SAT) are relatively fragile than their irrigated counterparts; and they are less productive especially under rain-fed conditions largely due to their unfavourable physical, chemical and biological characteristics. Recent research showed that unfavourable hydraulic properties of the SAT soils are among the major constraints to their agricultural productivity. However, these soils possess great resilience when they are appropriately managed by implementing improved soil, water and nutrient management practices ${ }^{1}$. It is critical for the natural resource managers to understand the causative factors that lead to their degradation and loss of productivity. Research to unfold the cause-effect relationship of the degradation of the SAT soils can help the natural resource managers to innovate methods to make soils resilient for productive agriculture. In this paper, results obtained through research efforts at the ICRISAT Center in Patancheru over the past four decades are discussed for their consideration and adoption in practical agriculture to enhancing the productivity of the SAT soils in India and elsewhere.

For the last several decades, the spatially associated red and black soils (shrink-swell soils) from the drier tracts are reported from the western, central and southern provinces of India ${ }^{2}$. The Central Arid Zone Research Institute (CAZRI) and Central Research Institute on Dry Land Agriculture (CRIDA) of the Indian Council of

\footnotetext{
*For correspondence. (e-mail: tapas11156@yahoo.com)

${ }^{\dagger}$ Deceased.
}

Agricultural Research (ICAR) have been carrying out research on these two soil types on various aspects for agricultural production. The International Crops Research Institute for the Semi-Arid Tropics (ICRISAT) is working on the resilience of dryland systems for the southern peninsula and a few African countries, whereas the International Center for Agricultural Research for the Dry Areas (ICARDA) has been engaged in broad areas of research in dryland agriculture. Despite organized research activities to improve the productivity of red and black soils by these institutes, the cause-effect relationships that limit crop yield were established by the pedologists of the ICAR more than a decade ago, who identified that the pedogenic formation of calcium carbonate (PC) is the main cause for natural chemical degradation of the SAT $\operatorname{soils}^{3-8}$. Understanding of the causeeffect relationship has helped to rehabilitate these soils by implementing appropriate soil, water and nutrient management interventions. The present article is a synthesis of such research that has the potential to restore the resilience and enhance the productivity of the SAT soils.

\section{SAT soils and their extent}

Total areas of associated red and black soils in the SAT were determined during a World Bank sponsored National Agricultural Technology Project (NATP), which aimed to identify production systems for organic carbon sequestration, for increasing productivity ${ }^{9}$ (Table 1). The other objective of this project was to prioritize areas for organic carbon sequestration and also for conservation agriculture; during this exercise, the revised area was worked out to be $151.8 \mathrm{~m}$ ha (refs 10,11$)$.

\section{Are the SAT soils inherently less productive?}

SAT soils are basically resilient because they respond to various management interventions to emerge as a productive system. These soils are chemically degraded; and are considered as naturally degraded soils. These climatically induced chemically degraded soils are less productive and commonly confined in the SAT areas of the peninsular and extra-peninsular India ${ }^{5}$. These soils are calcareous and sodic; and are hard to till when dry and often require chemical ameliorant to bring them back to normal soils in terms of chemical and physical properties ${ }^{6}$. 


\section{What makes SAT soils less productive?}

It is quite often observed that carbon sequestration in soils is related to only organic carbon; although carbon exists in soils in two different forms, viz. organic and inorganic. Inorganic carbon sequestration however involves chemical reactions in the pedo-environment ${ }^{6}$ and the formation of pedogenic $\mathrm{CaCO}_{3}(\mathrm{PC})$ is responsible for the SAT soils to be less productive. The mechanism of PC formation is as follows:

The atmospheric $\mathrm{CO}_{2}$ formed by respiration of the roots and small animals (both macro and micro) form $\mathrm{H}_{2} \mathrm{CO}_{3}$ in an aqueous solution in soils.

$$
\mathrm{CO}_{2} \text { (gas) }+\mathrm{H}_{2} \mathrm{O} \text { (liquid) } \rightarrow \mathrm{H}_{2} \mathrm{CO}_{3} \text { (liquid). }
$$

The generally higher level of soluble and exchangeable $\mathrm{Ca}^{2+}$ ions react with $\mathrm{H}_{2} \mathrm{CO}_{3}$ to form soluble $\mathrm{Ca}\left(\mathrm{HCO}_{3}\right)_{2}$ in the soil environment.

$$
\mathrm{Ca}^{2+}+\mathrm{H}_{2} \mathrm{CO}_{3} \rightarrow \mathrm{Ca}\left(\mathrm{HCO}_{3}\right)_{2} .
$$

Calcium bicarbonate $\left[\mathrm{Ca}\left(\mathrm{HCO}_{3}\right)_{2}\right]$ being soluble moves down the soil profile in high mean annual rainfall (MAR) areas like in per-humid, humid and sub-humid (moist) bio-climates and gets concentrated deep down the soil profile, leaving the soil control section non-calcareous ${ }^{6}$.

Table 1. Benchmark soils in the semi-arid tropics, representing associated red and black

\begin{tabular}{|c|c|}
\hline Soil series & Area $(, 000 \mathrm{ha})$ \\
\hline Teligi & 659 \\
\hline Sarol & 721 \\
\hline Asra & 1866.4 \\
\hline Vijaypura & 841 \\
\hline Sokhda & 604.4 \\
\hline Paral & 1185 \\
\hline Kheri & 464.1 \\
\hline Linga & 129.5 \\
\hline Kaukuntla & 755.6 \\
\hline Jajapur & 1153.3 \\
\hline Semla & 485.7 \\
\hline Palathurai & 345.1 \\
\hline Kalwan & 618.9 \\
\hline Patancheru & 1462.5 \\
\hline Kasireddipalli & 391.3 \\
\hline Nimone & 46.5 \\
\hline Panjri & 635.9 \\
\hline Jhalipura & 1153.7 \\
\hline Nabibagh & 486.9 \\
\hline Nipani & 533.4 \\
\hline Pangidi & 1021.1 \\
\hline Dadarghugri & 138.66 \\
\hline Boripani & 1673.1 \\
\hline Bhatumbra & 259.9 \\
\hline Konheri & 362.5 \\
\hline Kovilpatti & 1291.5 \\
\hline Hayatnagar & 1725.2 \\
\hline Karkeli & 623.9 \\
\hline
\end{tabular}
soils
However, in low MAR areas $(<900 \mathrm{~mm}$ MAR) the pedo environment is seasonally dry, which leads to the formation of $\mathrm{PC}$ as powdery lime following this equation

$$
\mathrm{Ca}\left(\mathrm{HCO}_{3}\right)_{2} \rightarrow \underset{\text { Atmosphere }}{\mathrm{CaCO}_{3} \downarrow}+\mathrm{H}_{2} \mathrm{O}+\mathrm{CO}_{2} \uparrow .
$$

Over time these powdery lime particles accumulate to form lime concretions (conca). The depth function of PC shows an increasing trend ${ }^{12}$. On many occasions the surface soils $\left(0-25 \mathrm{~cm}\right.$ depth) may be devoid of $\mathrm{CaCO}_{3}$ but the subsurface indicates its richness. The depth function of $\mathrm{CaCO}_{3}$ is related to $\mathrm{MAR}^{8}$ and are designated as concas called $\mathrm{PCs}^{3}$, which are responsible in modifying some important chemical and physical properties to make the SAT soils chemically degraded and less productive ${ }^{5}$.

The above stated reaction leads to increase in soil $\mathrm{pH}$ and also the relative abundance of $\mathrm{Na}^{+}$ions on both soil exchange sites and solution, which impairs the soil productivity (Figure 1). Roth $C$ model exercise arrived at a threshold limit of MAR of $850 \mathrm{~mm}$ while determining SOC turnover rate. This threshold MAR is further supported by soil survey data that describe inorganic carbon sequestration and concomitant development of subsoil sodicity $^{8}$.

\section{Consequences of SAT soils being less productive}

Organic and inorganic carbon contents of the soil are directly governed by climate (Figure 1). In fact, climatic aridity allows sequestration of more carbon in inorganic form and less in organic form.

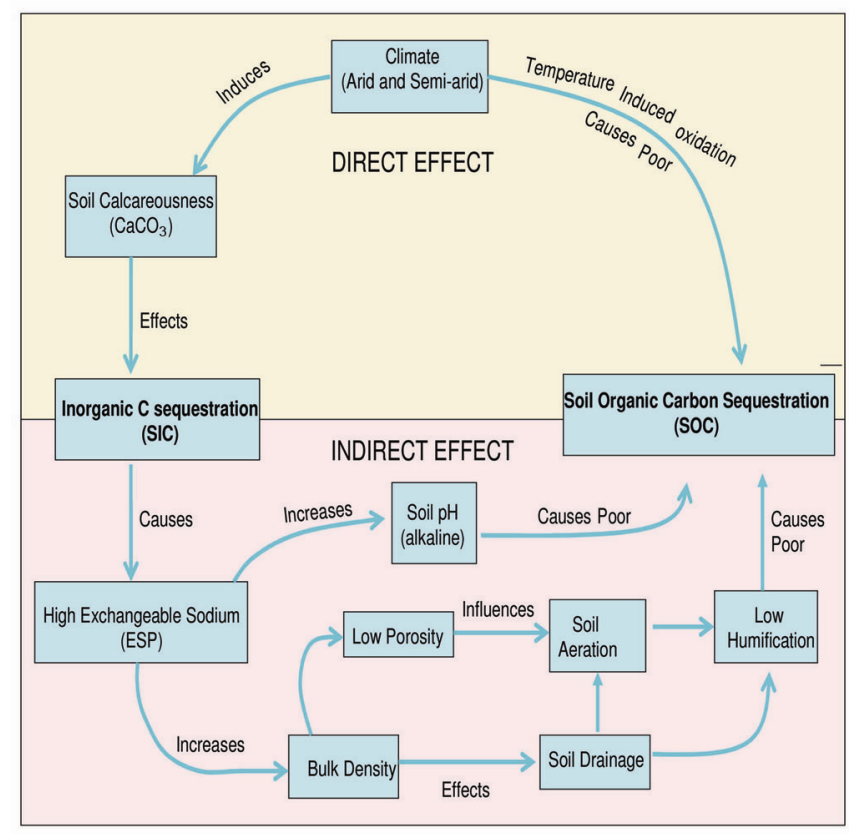

Figure 1. Inorganic carbon sequestration in SAT soils as influenced by soil properties under natural conditions (Source: Bhattacharyya et al. ${ }^{17}$ ). 


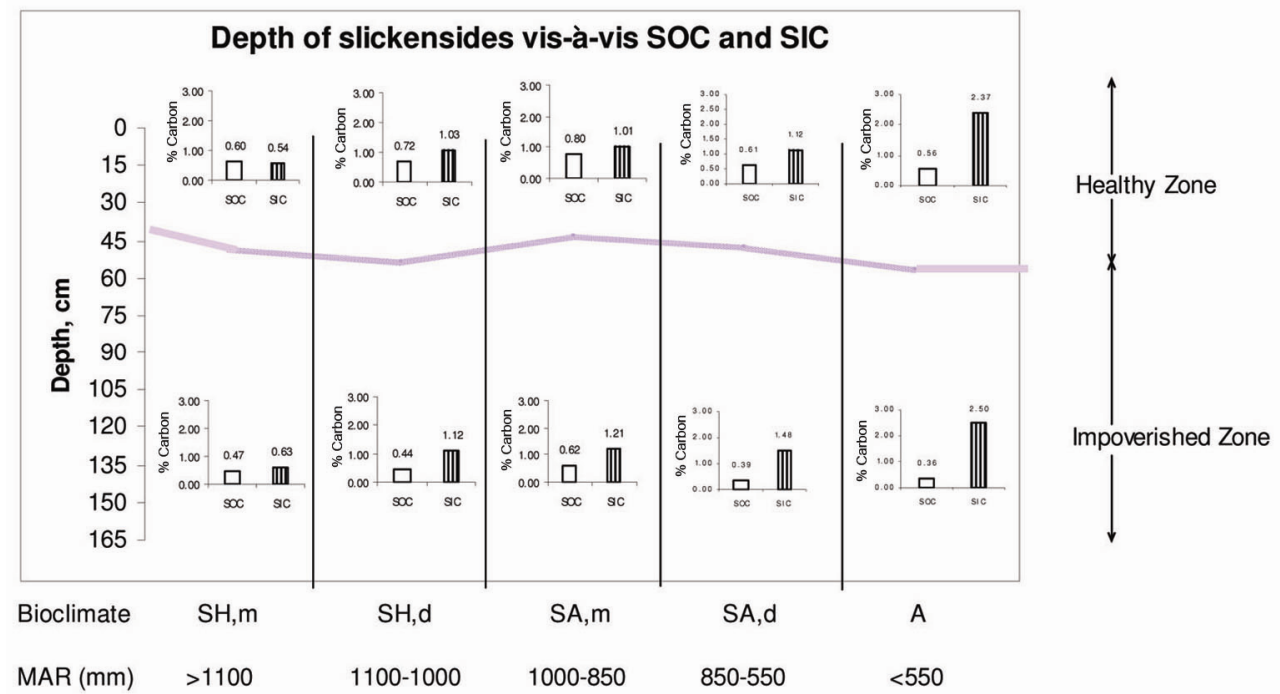

Figure 2. Depth of occurrence of slickensides (shown by darker line) vis-à-vis SOC and SIC.

By and large, the SAT soils are dominated by black soils (Vertisols and their intergrades) ${ }^{13}$ which are characterized by slickensides as important subsurface morphological feature ${ }^{14}$. It is observed that the depth of initiation of slickensides in the soils varies according to the bioclimatic system (Figure 2). It has been stated that higher soil inorganic carbon (SIC) makes a soil more sodic in the subsoils that cause natural chemical degradation of soils ${ }^{5}$. We find that in the SAT soils that the zone above slickensides varies from $56 \mathrm{~cm}$ to $26 \mathrm{~cm}$ as one traverses from more to less MAR area (Figure 2). And since these soils contain more SOC and less SIC at the stated depths, it may be considered relatively safe zone compared to the zone below the depth of slickensides ${ }^{15-17}$ to plan various crops with better yields. In addition, soil grouping ${ }^{14}$ indicates the influence of climate change which should aid planners and scientists to assess the degree of soil degradation $^{8}$. The results of the study suggest that up to a threshold limit of $800 \mathrm{~mm}$ MAR (subhumid moist dry and semi-arid moist), the majority of the black soils is grouped as Typic Haplusterts. The Gypsic and Calcic Haplusterts are confined only in the semi-arid dry system with a MAR of $800-550 \mathrm{~mm}$. The Sodic Haplusterts occur in semi-arid (dry) bioclimatic system and gradually these soils dominate the entire arid system showing decrease in SOC and increase in SIC (Figure 2) ${ }^{15-17}$. Such taxonomic grouping of soils showing different subgroup levels related to MAR facilitates a better understanding of the degraded soils and their reclamation to enhance their resilience as shown in Figure 2.

\section{Resilience of SAT soils}

Following the basic chemical reaction of $\mathrm{Ca}^{2+}$ ions precipitated for the formation of PC in SAT soils, it becomes easy to innovate the management protocols to make the SAT soils resilient by bringing back immobilized $\mathrm{Ca}^{2+}$ ions (as PC) into soil solutions. The management protocols to reclaim such degraded soils can be through the following two ways: (i) Quick/fast track amelioration and (ii) Relatively slow process of amelioration.

\section{(i) Quick/fast track amelioration}

This method is meant for bringing back these soils to normal condition using chemical treatments. The sodic soils are treated with gypsum with a recommended dose of $10 \mathrm{tha}^{-1}$ with irrigation by good quality water followed by paddy cultivation ${ }^{18}$. This technique nevertheless shall rectify the surface soils only. The lower horizons will still remain sodic. Such technique, therefore, may be beneficial if the crops grown are shallow rooted, but the cropping needs to be continued to arrest the rise of further sodicity in the soil profile. Although this technique is a rapid one, it is not cheap as the farmers need to buy gypsum.

\section{(ii) Slow process}

The preventive and ameliorative measures to protect the SAT deep black soils from degradation are slow processes but they are sustainable in the long run and may restore soil quality for a long time.

It has been reported that in soils of dry bioclimate, exchangeable sodium percentage (ESP) and $\mathrm{CaCO}_{3}$ content increase with pedon depth ${ }^{3}$. This depth function suggests that due to the formation of $\mathrm{CaCO}_{3}$, sodicity initially develops in the subsoil region. As mentioned earlier, the sodicity gradually rise in the entire profile, 
rendering the soil unproductive in the SAT regions. Since gypsum treatment is limited to correcting soils in the surface layers, we suggest that deep rooted perennial crops could be an alternate option not only for prevention but also to rectify soils which have already become sodic. Such crops might include a host of agricultural and horticultural crops, agro-forestry species and even some tree species.

The native $\mathrm{CaCO}_{3}$ gets dissolved through the action of acidic root exudates and carbonic acid formed due to evolved carbon-di-oxide from root respiration in aqueous solution. The formation of soluble calcium bicarbonate restores the soil environment as shown by the following reactions:

$$
\begin{aligned}
& \mathrm{CaCO}_{3}+\mathrm{H}_{2} \mathrm{O}+\mathrm{CO}_{2} \rightarrow \mathrm{Ca}\left(\mathrm{HCO}_{3}\right)_{2}, \\
& \mathrm{Ca}\left(\mathrm{HCO}_{3}\right)_{2} \rightarrow \mathrm{CaCO}_{3}+\mathrm{H}_{2} \mathrm{O}+\mathrm{CO}_{2} .
\end{aligned}
$$

The soluble calcium bicarbonate helps restoring the soluble and exchangeable $\mathrm{Ca}$ levels in soils, decreasing ESP and improving soil structure to increase hydraulic conductivity (HC). The $\mathrm{CO}_{2}$ evolved goes back to atmosphere and thus makes the cycle complete ${ }^{6}$.

\section{Natural process of resilience in SAT soils}

In principle, all sodic soils are calcareous but all calcareous soils are not sodic. As sodicity de facto refers to chemical degradation of soil it is said that all degraded soils in the SAT are calcareous; however, all calcareous soils may not be degraded. This needs clarification.

Calcareous soils refer to soils that contain $\mathrm{CaCO}_{3}$ which can be either pedogenic (PC) or non-pedogenic (NPC). NPCs (as a part of soil parent material) are boon for farmers and these are mostly concentrated in soils of wetter climatic regions and these soils are not sodic ${ }^{19}$. Detailed studies on SAT soils indicate that these are often zeolitized $^{20}$ and such soils cover nearly $2 \mathrm{~m}$ ha in India. These zeolitized soils, rich in $\mathrm{Ca}^{2+}$ ions, are often calcareous $^{8,19}$. These Ca-rich zeolites have been termed as natural soil modifiers ${ }^{21,22}$. Besides zeolites, SAT soils also contain another soil modifier like gypsum ${ }^{13}$. The gypsiferous soils, even in the presence of $\mathrm{CaCO}_{3}$, never allow soils to degrade as evidenced by their better drainage $^{3}$ and crop performance ${ }^{23}$. Besides, Ca-zeolites and gypsum, NPCs, as mentioned earlier, help maintain soil quality as evidenced by relatively neutral $\mathrm{pH}$ in otherwise acidic soil areas in the north-eastern region ${ }^{19}$.

The soil modifiers are grouped into two types, viz. favourable and unfavourable natural endowments. Gypsum, Ca-rich zeolites and NPCs are the favourable soil modifiers and the unfavourable ones are palygorskite and pedogenic carbonates (PCs). Recent evidence however, shows that PCs could also help in reclaiming SAT soils under suitable management interventions ${ }^{5}$.

\section{Way forward}

Soils have inherent capacity to resist changes that control pedological and edaphic characteristics. For example, the lighter textured soils of the Indo-Gangetic Plains become more prone to quick formation of $\mathrm{CaCO}_{3}$, but even at an ESP of $\leq 40$ these soils remain productive under rice/ wheat cropping system. In contrast, the deep SAT black soils of the peninsular India resist changes in ESP due to high amount of expanding clays, but they become impervious even in low ESP of 5 or so. And if these soils are not amended, the ESP increases, making these soils impervious. This is common in western part of the country. To make things worse, the poor quality of irrigation water makes these soils hard and impervious ${ }^{24}$. The SAT soils in peninsular India require special attention as reclaiming these soils is expensive and time-consuming compared to the SAT soils in the IGP.

The soils of the SAT area need care and attention. They are fragile and are in sensitive ecosystem since the causative factors act slowly to make these soils chemically and physically inactive. The process starts at the bottom layers, invisible to human eye and due to climate change it gradually engulfs the entire soil depth. The calcium carbonate nodule formation is not detected by remotely sensed data until there is an external manifestation in the form of hardiness at the surface layer of soil to the point that run off supersedes infiltration, causing flash flood. With the help of proper knowledge of the fertility of the SAT soils ${ }^{25}$, adopting appropriate water management practices ${ }^{5,8}$ with special reference to waste water $^{26}$, supply of seeds, plant protection mechanisms and proper livelihood security ${ }^{27}$ there can be a perceptible change in the farming of SAT areas.

The important issue in SAT soil management should encompass whether these soils should be under agriculture or not. As explained earlier, deep rooted perennial trees (horticulture etc.) can keep these soils in good condition - (i) by dissolving the hidden $\mathrm{CaCO}_{3}$ below the surface and (ii) more importantly, keeping the surface cover protected and thus to keep the causes of soil dryness at bay. Policymakers and land resource managers including plant scientists have a role to play.

1. Sahrawat, K. L., Wani, S. P., Pathak, P. and Rego, T. J., Managing natural resources of watersheds in the semi-arid tropics for improved soil and water quality: a review. Agric. Water Manage., 2010, 97, 375-381.

2. Bhattacharyya, T. et al., Soils of India: Historical perspective, classification and recent advances in knowledge: a review. Curr. Sci., 2013, 104, 1308-1323.

3. Pal, D. K., Dasog, G. S., Vadivelu, S., Ahuja, R. L. and Bhattacharyya, T., Secondary calcium carbonate in soils of arid and semi-arid regions of India. In Global Climate Change and Pedogenic carbonates (eds Lal, R. et al.), Published by Lewis Publishers, Boca Ratan, 2000, pp. 149-185. 


\section{SPECIAL SECTION: SOIL AND WATER MANAGEMENT}

4. Pal, D. K. et al., Vertisols (cracking clay soils) in a climosequence of Peninsular India: Evidence for Holocene climate changes. Quaternary Int., 2009, 209, 1-16.

5. Pal, D. K., Bhattacharyya, T., Sahrawat, K. L. and Wani, S. P., Natural chemical degradation of soils in the Indian semi arid tropics, and remedial measures: a review. Curr. Sci., 2016, 110(9), 1675-1682.

6. Bhattacharyya, T., Pal, D. K., Chandran, P., Mandal, C., Ray, S. K., Gupta, R. K. and Gajbhiye, K. S., Managing soil carbon stocks in the Indo-Gangetic plains, India, Rice-Wheat Consortium for the Indo-Gangetic Plains, New Delhi, 2004, p. 44.

7. Bhattacharyya, T., Chandran, P. and Ray, S. K., Soil classification following US taxonomy: an Indian commentary. Soil Horizon, 2015. 1-16; doi: 10.2136/sh14-08-0011.

8. Bhattacharyya, T. et al., ICRISAT, India soils: yesterday, today and tomorrow. Curr. Sci., 2016, 110(9), 1652-1670.

9. Bhattacharyya, T. et al., Estimation of carbon stocks in the red and black soils of selected benchmark spots in semi-arid tropics, India, Global Theme on Agro Ecosystems Report No. 28, NBSSLUP, and ICRISAT (India), 2006, p. 86.

10. Bhattacharyya, T., Pal, D. K., Chandran, P., Ray, S. K., Mandal, C. and Telpande, B., Soil carbon storage capacity as a tool to prioritise areas for carbon sequestration. Curr. Sci., 2008, 95, 482-494.

11. Bhattacharyya, T. et al., Georeferenced Soil Information System: Assessment of Database. Curr. Sci., 2014, 107, 1400-1419.

12. Pal, D. K., Wani, S. P. and Sahrawat, K. L., Carbon sequestration in Indian soils: Present status and the potential. Proc. Nat. Acad. Sci., Biol. Sci. (NASB), India. 2015, 85, 337-358; doi: 10.1007/ s40011-014-0351-6.

13. Bhattacharyya, T. et al., Characterization of benchmark spots of selected red and black soils in semi-arid tropics of India for identifying systems for carbon sequestration and increased productivity in semi-arid tropical environments, Global Theme on Agro Ecosystems Report No. 42, Working report of identifying systems for carbon sequestration and increased productivity in semi-arid tropical environments (RNPS-25), National Agricultural Technology Project (NATP), Indian Council of Agricultural Research (ICAR), New Delhi, India, Patancheru, Andhra Pradesh, India: International Crops Research Institute for the Semi-Arid Tropics (ICRISAT), and New Delhi, India: Indian Council of Agricultural Research, 2008, p. 388.

14. Soil Survey Staff. Keys to Soil Taxonomy, USDA-NRCS, Washington, DC, 2014, 12th edn.

15. Bhattacharyya, T. et al., Carbon sequestration in red and black soils I. Influence of morphological properties. Agropedology, 2007, 17, 1-15.
16. Bhattacharyya, T. et al., Carbon sequestration in red and black soils II. Influence of physical and chemical properties. Agropedo$\log y, 2007,17,16-25$.

17. Bhattacharyya, T. et al., Carbon sequestration in red and black soils III. Identifying systems through carbon stock and bulk density of soils. Agropedology, 2007, 17, 26-34.

18. Abrol, I. P. and Fireman, M., Alkali and Saline Soils; Identification and Improvement for Crop Production, Bulletin No. 4. Central Soil Salinity Research Institute, Karnal, India, 1977.

19. Bhattacharyya, T., Sehgal, J. and Sarkar, D., Soils of Tripura for Optimizing Land Use: Their Kinds, Distribution and Suitability for Major Field Crops and Rubber, NBSS Publ. 65 a and c (Soils of India series 6). NBSS \& LUP, Nagpur, India, 1996, p. 154.

20. Bhattacharyya, T., Chandran, P., Ray, S. K., Pal, D. K., Mandal, C. and Mandal, D. K., Distribution of zeolitic soils in India: an update. Curr. Sci., 2015, 109(7), 1305-1313.

21. Pal, D. K., Bhattacharyya, T., Ray, S. K., Chandran, P., Srivastava, P., Durge, S. L. and Bhuse, S. R., Significance of soil modifiers (Ca-zeolites and gypsum) in naturally degraded Vertisols of the Peninsular India in redefining the sodic soils. Geoderma, 2006, 136, 210-228.

22. Bhattacharyya, T., Pal, D. K. Lal, S., Chandran, P. and Ray, S. K., Formation and persistence of Mollisols on Zeolitic Deccan basalt of humid tropical India. Geoderma, 2006, 136, 609-620.

23. Bhattacharyya, T. et al., Estimation of carbon stocks in the red and black soils of selected benchmark spots in semi-arid tropics, India, Global Theme on Agro Ecosystems Report No. 28, NBSSLUP and ICRISAT (India), 2006, p. 86.

24. Padekar, D. G., Bhattacharyya, T., Deshmukh, P. D., Ray, S. K., Chandran, P. and Tiwary, P., Is irrigation water causing degradation in black soils? Curr. Sci., 2014, 106, 1487-1489.

25. Sahrawat, K. L., How fertile are semi-arid tropical soils? Curr. Sci., 2016, 110(9), 1671-1674.

26. Datta, A., Wani, S. P., Patil, M. D. and Tilak, A. S., Field scale evaluation of seasonal wastewater treatment efficiencies of freesurface-constructed wetlands in ICRISAT, India. Curr. Sci., 2016, 110(9), 1756-1763.

27. Petare, K. J., Nayak, J., Jaini, V. and Wani, S. P., Livelihood system assessment and planning for poverty alleviation: a case of rainfed agriculture in Jharkhand. Curr. Sci., 2016, 110(9), 17731783.

doi: $10.18520 / \mathrm{cs} / \mathrm{v} 110 / \mathrm{i} 9 / 1784-1788$ 